\title{
Understanding Entrepreneurial Passion Among New Entrepreneurs
}

\author{
Beatrice Mayoshe ${ }^{1}$ Kartika Nuringsih ${ }^{1 *}$ \\ ${ }^{1}$ Faculty of Economics \& Business, Universitas Tarumanagara, West Jakarta 11470, Indonesia \\ "Corresponding author. Email: kartikan@fe.untar.ac.id
}

\begin{abstract}
In line with entrepreneurial learning, the study identified a significant effect of emotional support, perceived competence, and entrepreneurship education toward entrepreneurial passion among entrepreneurship in Jakarta. A total of 100 respondents were involved in this study using non-probability techniques sampling. The data analysis technique used multiple regression with Smart-Pls software. The results show emotional support has the strongest influence in building passion, on the contrary, perceived competence has the smallest effect on passion. In line with Social Learning Theory, the independent variables can increase selfefficacy in entrepreneurs so that they are more enthusiastic for creating and product development, founding and developing the venture. The majority of the samples are new entrepreneurs who are in early development and start-up stages so that educational institutions and the government have the responsibility in building an entrepreneurial atmosphere so that it will automatically build an entrepreneurial passion for the younger generation. This mechanism can encourage passion awareness for youth entrepreneurs so this is a step in achieving the target of the ideal number of educated entrepreneurs in Indonesia.
\end{abstract}

\section{Keywords: Emotional support, perceived competence, entrepreneurship education, entrepreneurial passion}

\section{INTRODUCTION}

Entrepreneurship is an important aspect of economic development with an orientation to increase welfare and lower unemployment. The government encourages entrepreneurial activities through a stimulus program, mentoring, and education for aspiring entrepreneurs. Nowadays, the interest in entrepreneurship is important to create social welfare, so that entrepreneurship education is provided through schools and universities. This is an effort to achieve the ideal number of entrepreneurs for a country. In order to ensure business sustainability, a psychological foundation is needed, namely entrepreneurial passion such as the passion for inventing, founding, or developing a new venture [1]. Indeed, study of [2] stated that there is an impact of this passion for entrepreneurial intention. Based on these reasons, the existence of this passion helps entrepreneurs in dealing with entrepreneurial processes so that it will support readiness in facing the stages of the venture life cycle.

Previous studies of Cordon and Kirk stated the passion is related to the persistence and sustaining the entrepreneurial action [3]. But in fact, many businesses initiated by young people or students have been unsuccessful. For example, not many students who take part in business simulation projects continue to become real start-ups. If anyone continues even then in very limited numbers. Thus this may be related to passion. Therefore, a study of these aspects was conducted.
One of the human traits that are difficult to control is an emotion so that the ability to maintain emotions is related to managing passion. Moreover, it is very important to control these emotions. According to Cordon et al. "entrepreneurial emotion refers to the influence, emotions, moods, and/or feelings of individuals or collectives" [4]. This is a consequence of the entrepreneurial process so that it relates to the ability to recognize, evaluate, reform, and seize opportunities. Understanding emotions is important for entrepreneurs to have positive feelings in carrying out their entrepreneurial activities. An expected condition is that emotions support the formation of entrepreneurial passion [1]. The emotional support in the form of information, resource, or financial support provided by the environment closest to the entrepreneur or social networking. In other words, emotional support is a sense of empathy given by other people or the social community to new entrepreneurs. With this support, emotionally a new entrepreneur will be stronger in facing challenges or obstacles than those who do not receive the support. Therefore, this aspect is assessed in identifying its effect on passion. This effect is proven by Stenholm and Nielsen that the perceived of emotional support is positively associated with entrepreneurial passion [5]. By considering these results, the construct of the perceived emotional support is used as a predictor in this study.

The other factor formed by competence such as experience related to the entrepreneurial career path [5], previous experience, and entrepreneurial tenure [1]. With these competencies, entrepreneurs are more skilled and 
experienced in overcoming problems and are more concerned with seizing opportunities. With competence, new entrepreneurs are more easily undergo the start-up period and the next stages of the life cycle so that it has a positive effect on entrepreneurial passion. Basically, entrepreneurs feel self-efficacy, but this self-confidence can fluctuate in line with changes in business conditions, for example in pandemic situations, economic crises, natural disaster factors, or others.

The last factor which is considered to impact this passion is education level [1]. Entrepreneurial education can form the mindset about entrepreneurial activities so that can promote passion among entrepreneurs. More precisely, Arshad et al. stated entrepreneurship education can build self-efficacy in a person so that passionate about building entrepreneurship [6]. By owning this passion can foster entrepreneurial intention. [7] Identified a significant relationship between entrepreneurial education and entrepreneurial intention on Indonesian respondents so that our research considers the effect of entrepreneurial education toward entrepreneurial passion among enterprise owners. Education will improve their sense of self-efficacy in running the new business so that they are more enthusiastic to be an entrepreneur.

Finally, the goal of the study is to investigate the impact of these variables such as emotional support, perceived competence, and entrepreneurship education on shaping entrepreneurial passion among entrepreneurs in Daerah Khusus Ibukota (DKI) Jakarta province. Based on Social Learning Theory from Bandura, some hypotheses were tested in this study. The result is expected to be suggestions for the government and educational institutions in evaluating the entrepreneurial development programs, specifically how to boost the passion among entrepreneurs. It is important to foster performance and sustainability of new ventures through improving the early seed financing, government grant, training and assistance to new entrepreneurs, provide market access and licensing, or others. Through these actions will be encouraged passion awareness among entrepreneurs so that feel proud and confident in their identity as the founder of a business.

\section{LITERATURE REVIEWS}

\subsection{Understanding Entrepreneurial Passion}

According to Cordon and Kirk stated the passion is related to the persistence and sustaining the entrepreneurial action [3]. Thus, it has an impact on entrepreneurial behavior [8]. With this passion, entrepreneurs could improve their entrepreneurial attitude so that it will impact venture creation, venture funding, and other outcomes [1]. Therefore, entrepreneurial passion plays an important role in entrepreneurial activities [9], owns a relation to the emotion [10], and impacts to the creativity and persistence [11]. By owning this passion, entrepreneurs demonstrate transformational leadership to their employees [12] while Cordon et al. noted the meaning of entrepreneurial passion as "consciously accessible positive intense feelings experienced by engagement in entrepreneurial activities" [9]. Particularly, it is an identity for the entrepreneur. Further, Merieska and Meiyanto highlighted the role of the passion among new entrepreneurs for creating and product development, founding and developing their venture [13]. It proves the impact of passion on the venture performance [14]. For these reasons, it is important owned by entrepreneurs so the study directs for identifying factors of entrepreneurial passion.

\subsection{Developing Hypothesis}

The stages of developing the hypothesis as follows. Firstly, the research model places three variables e.g., emotional support, perceived competence, and entrepreneurship education on shaping entrepreneurial passion among entrepreneurs. This effect is proven by Stenholm and Nielsen that the perceived emotional support is positively associated with entrepreneurial passion [5]. By considering these results, the construct of the perceived emotional support is used as a predictor in this study.

Secondly, based on [5], the term of competence was stated as the task-relatedness of competencies which "is understood as the degree to which skills and competencies are related and transferrable to the tasks and challenges associated with being an entrepreneur". With competence, new entrepreneurs are more easily undergo the start-up period and the next stages of the life cycle so that it has a positive effect on entrepreneurial passion.

Thirdly, the other factor is considered to impact this passion is education level [1]. Entrepreneurial education can form the mind-set about entrepreneurial activities so that can promote passion among entrepreneurs. More precisely, Arshad et al. stated entrepreneurship education can build self-efficacy in a person so that passionate about building entrepreneurship [6].

Based on these relationships, the development of some hypotheses are as follows:

- H1: Emotional support has a positive effect significantly on the entrepreneurial passion.

- H2: Perceived competence has a positive effect significantly on the entrepreneurial passion.

- H3: Entrepreneurship education has a positive effect significantly on the entrepreneurial passion

\section{METHODS}

The stages of the research method are as follows: Firstly, the population involved entrepreneurs in Jakarta while the sampling technique uses non-probability sampling so that not all members of the population get the same chance of being selected as the sample. The purposive sampling method is used to determine the sample with the consideration e.g., entrepreneurs domicile in DKI Jakarta province, receive seed early financing assistance at the beginning of starting a business, and have been in business for at least six months. The sample size as many as 100 entrepreneurs consisting of East Jakarta (5\%), South Jakarta (6\%), Central Jakarta (7\%), North Jakarta (35\%), 
and West Jakarta (47\%). This proportion is just a coincidence, basically, all areas in Jakarta have the same potential for entrepreneurial development.

Secondly, the model consists of three variables to predict the entrepreneurial passion. There are emotional support, perceived competence, and entrepreneurship education which are positioned as independent variables. The next picturizing of the research model seems as the bootstrapping result in Figure 1. The Instruments are designed from some previous studies such as Stenholm and Nielsen for four items of emotional support [5], Davidsson and Honig for four items of competence [15], Vandewalle for six items of learning goal orientation to capture their perception about education among entrepreneurs [16], and back to [5] for ten items of entrepreneurial passion. Totally, the study involves 24 indicators that were used as the instruments.

The instrument is arranged in the questionnaire and to be installed to the google form with using a Likert scale from 1 (strongly disagree) until 5 (strongly agree). Testing the validity and reliability to ensure data quality, which in the validity test uses convergent and discriminant validity, while reliability test uses composite reliability and Cronbach's Alpha. The data analysis technique uses multiple regression with processing using Smart-Pls.

Thirdly, it performs quantitative analysis and hypothesis testing. Based on the results, it was preparated to make suggestions and implications for government and institutional education related to fostering passion among, newcomers or nascent entrepreneurs/enterprise owners. The limitations of this study are described so that further research can improve a more appropriate model in understanding entrepreneurial passion.

\section{FINDINGS AND DISCUSSIONS}

\subsection{Respondents' Profiles}

Respondents consisted of men (60\%) and women (40\%). The ages ranged from $20-30$ years $(51 \%)$, more than 50 years $(21 \%), 41-50$ years $(15 \%), 31-40$ years $(9 \%)$ while less than 20 years (4\%). The results show the interest of youth entrepreneurs and seem to become a passion. Therefore, this is relevant to government programs in promoting entrepreneurship for millennials.

Furthermore, respondents with a postgraduate educational background $(1 \%)$, undergraduate level $(47 \%)$, diploma $(5 \%)$, and high school (47\%). It is shown that there are as many high school graduates as undergraduate degrees, so it needs support from the government or stakeholders to encourage their performance and passion.

Received early funding from parents $(71 \%)$, investors $(15 \%)$, family $(6 \%)$, government grants $(2 \%)$, and the rest from business partners. This shows that the majority of entrepreneurs get seed financing from their parents. This is because they are in the development stage so that creditors/banks have not trusted them.

Regarding the length of time running a business, $42 \%$ have been self-employed for 6 months- 1 years, $24 \%$ for $2-5$ years, $13 \%$ for $6-10$ years, and $21 \%$ for more than 11 years. This shows that the majority of respondents are at the development stage or early start-up so that they require stakeholder's support to be able to maintain business performance in the early stages until completing the startup period.

Table 1 Validity and Reliability Instruments

\begin{tabular}{|c|c|c|c|c|c|c|}
\hline Variables & Items & $\begin{array}{l}\text { Loading } \\
\text { Factor }\end{array}$ & Status & $\begin{array}{l}\text { Composite } \\
\text { Reliability }\end{array}$ & $\begin{array}{c}\text { Cronbach's } \\
\text { Alpha }\end{array}$ & Status \\
\hline \multirow{3}{*}{$\begin{array}{l}\text { Emotional } \\
\text { Support }\end{array}$} & ES4 & 0.796 & Valid & \multirow{3}{*}{0.813} & \multirow{3}{*}{0.657} & \multirow{3}{*}{ Reliable } \\
\hline & ES2 & 0.779 & Valid & & & \\
\hline & ES3 & 0.732 & Valid & & & \\
\hline \multirow{3}{*}{$\begin{array}{l}\text { Perceived } \\
\text { Competence }\end{array}$} & PC2 & 0.878 & Valid & \multirow{3}{*}{0.828} & \multirow{3}{*}{0.751} & \multirow{3}{*}{ Reliable } \\
\hline & PC4 & 0.758 & Valid & & & \\
\hline & PC3 & 0.713 & Valid & & & \\
\hline \multirow{4}{*}{$\begin{array}{l}\text { Entrepreneurship } \\
\text { Education }\end{array}$} & EE2 & 0.809 & Valid & \multirow{4}{*}{0.853} & \multirow{4}{*}{0.771} & \multirow{4}{*}{ Reliable } \\
\hline & EE3 & 0.803 & Valid & & & \\
\hline & EE4 & 0.758 & Valid & & & \\
\hline & EE1 & 0.704 & Valid & & & \\
\hline \multirow{5}{*}{$\begin{array}{l}\text { Entrepreneurial } \\
\text { Passion }\end{array}$} & EP8 & 0.805 & Valid & \multirow{5}{*}{0.876} & \multirow{5}{*}{0.825} & \multirow{5}{*}{ Reliable } \\
\hline & EP5 & 0.789 & Valid & & & \\
\hline & EP6 & 0.784 & Valid & & & \\
\hline & EP3 & 0.727 & Valid & & & \\
\hline & EP7 & 0.722 & Valid & & & \\
\hline
\end{tabular}


Table 2 The Scores of Cross-Loading

\begin{tabular}{|c|c|c|c|c|}
\hline Indicators & $\begin{array}{c}\text { Perceived } \\
\text { Competence }\end{array}$ & $\begin{array}{c}\text { Entrepreneurship } \\
\text { Education }\end{array}$ & $\begin{array}{c}\text { Entrepreneurial } \\
\text { Passion }\end{array}$ & $\begin{array}{c}\text { Emotional } \\
\text { Support }\end{array}$ \\
\hline PC2 & $\mathbf{0 . 8 7 8}$ & 0.401 & 0.369 & 0.067 \\
\hline PC4 & $\mathbf{0 . 7 5 8}$ & 0.222 & 0.203 & 0.199 \\
\hline PC3 & $\mathbf{0 . 7 1 3}$ & 0.140 & 0.099 & 0.091 \\
\hline EE2 & 0.335 & $\mathbf{0 . 8 0 9}$ & 0.302 & 0.123 \\
\hline EE3 & 0.233 & $\mathbf{0 . 8 0 3}$ & 0.405 & 0.191 \\
\hline EE4 & 0.253 & $\mathbf{0 . 7 5 8}$ & 0.283 & 0.093 \\
\hline EE1 & 0.359 & $\mathbf{0 . 7 0 4}$ & 0.307 & 0.234 \\
\hline EP8 & 0.267 & 0.397 & $\mathbf{0 . 8 0 5}$ & 0.398 \\
\hline EP5 & 0.322 & 0.352 & $\mathbf{0 . 7 8 9}$ & 0.537 \\
\hline EP6 & 0.252 & 0.373 & $\mathbf{0 . 7 8 4}$ & 0.419 \\
\hline EP3 & 0.185 & 0.333 & $\mathbf{0 . 7 2 7}$ & 0.288 \\
\hline EP7 & 0.255 & 0.179 & $\mathbf{0 . 7 2 2}$ & 0.458 \\
\hline ES4 & 0.218 & 0.148 & 0.483 & $\mathbf{0 . 7 9 6}$ \\
\hline ES2 & -0.004 & 0.184 & 0.394 & $\mathbf{0 . 7 7 9}$ \\
\hline ES3 & 0.073 & 0.162 & 0.405 & $\mathbf{0 . 7 3 2}$ \\
\hline
\end{tabular}

\subsection{Testings of Validity, Reliability, and Hypothesis}

The results of the validity test are shown in Table $\mathbf{1}$. After going through this test, the number of indicators decreased to 15 items, whereas previously there were 24 items. As an illustration of the number of items for each variable as follows: perceived emotional support (3), perceived competence (3), entrepreneurship education (4), and entrepreneurial passion (5). All indicators produce a loading factor value above 0.70 so that it is declared valid. Besides, the composite reliability value is greater than 0.80 and the majority of the Cronbach's Alpha value is above 0.70 so that it is declared reliable. Only the perceived emotional support results in a lower value but results in a high composite reliability value so it is declared reliable.

Table 2 shows the results of the second validity test based on the cross-loading value. It can be seen that the value of the cross-loading indicator for each construct produces a greater value than other constructs. It is shown the three indicators of perceived competence produce a loading value of $0.878 ; 0.758 ; 0.713$ where this value is higher than the loading value on other constructs. The same thing happened to the loading values of the other constructs. Furthermore, to ensure the validity of overall indicators in measuring constructs, it can be explained through Figure 1. The t-statistic value on each indicator is greater than 1.96 so that 15 items are declared valid. Thus, the data in this study are valid and reliable so that it can be continued for hypothesis testing.

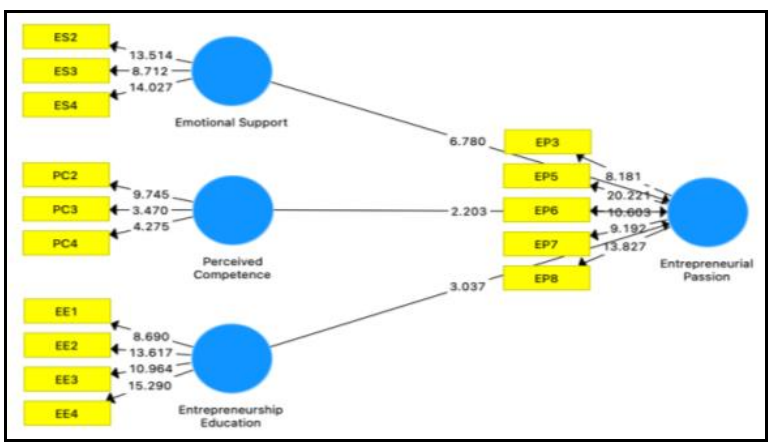

Figure 1 Bootstrapping of the Entrepreneurial Passion

Table 3 Path Coefficients

\begin{tabular}{|l|c|c|c|c|c|}
\hline \multicolumn{1}{|c|}{ Variables } & Coefficient & T-statistic & P-value & Hypothesis & Status \\
\hline $\begin{array}{l}\text { Emotional Support } \longrightarrow \\
\text { Entrepreneurial Passion }\end{array}$ & 0.480 & 7.063 & 0.000 & H1 & Accepted \\
\hline $\begin{array}{l}\text { Perceived Competence } \longrightarrow \\
\text { Entrepreneurial Passion }\end{array}$ & 0.178 & 2.165 & 0.031 & $\mathrm{H} 2$ & Accepted \\
\hline $\begin{array}{l}\text { Entrepreneurship Education } \longrightarrow \\
\text { Entrepreneurial Passion }\end{array}$ & 0.261 & 2.889 & 0.004 & $\mathrm{H} 3$ & Accepted \\
\hline $\mathrm{R}^{2}=\mathbf{0 . 4 4 1 7} ; \mathrm{Q}^{2}=\mathbf{0 . 2 4 0}$ Goodness of fit $=\mathbf{0 . 5 1 3 2}$ \\
\hline
\end{tabular}

Table 3 depicts the results of hypothesis testing. The relationship between perceived emotional support and entrepreneurial passion results in a p-value of 0.000 . It is lower than $1 \%$ so that $\mathbf{H 1}$ is accepted. Furthermore, the impact of perceived competence toward entrepreneurial passion results in a p-value of 0.031 . It is lower than $5 \%$ so $\mathbf{H 2}$ is also accepted. Lastly, the effect of entrepreneurship education on entrepreneurial passion results in a p-value of 
0.004. It is lower than $1 \%$ so that $\mathbf{H 3}$ is accepted. Based on these results it can be concluded that the three variables can be used as a mechanism to encourage a passion for entrepreneurs.

A further result is known the value of Q square value is 0.240 so it describes the predictive relevance at a moderate level. The goodness of fit as many as 0.5132 so this score is categorized as relatively large. Meanwhile, the coefficient of determination has a value of 0.441 so that the entrepreneurial passion model of $44.1 \%$ can be explained by the three independent variables.

The contribution of each variable is calculated as follows. First, the amount of emotional support contribution to entrepreneurial passion is 0.2688 (calculated as $0.480 \mathrm{x}$ 0.560*). The asterisk sign (*) is taken from the correlation score, in this case between emotional support and entrepreneurial passion. The same way is done to calculate the contribution on the other two variables. If entrepreneurs feel an increase in social-environmental support in the form of initial funds, their passion for entrepreneurship increases by $26.88 \%$. This contribution is relatively high because the majority of respondents are new entrepreneurs who have been running a business recently, so the existence of seed early financing is very meaningful in building a business so it affects their passion. Second, the contribution of perceived competence to entrepreneurial passion is $0.0607(0.178 \times \mathbf{0 . 3 4 1} *)$. If an entrepreneur feels an increase in competence in himself, his passion for entrepreneurship increases by $6.07 \%$. This contribution is relatively lower than emotional support so that it needs to be encouraged through mentoring mechanisms such as financial management training, licensing, tax payment, and others so that knowledge of these aspects becomes better and increases the passion for entrepreneurship.

Third, the contribution of entrepreneurship education to entrepreneurial passion is $0.11223(0.261 \times \mathbf{0 . 4 3 0} *)$. If entrepreneurs are willing to improve their education or getting knowledge so their passion in the entrepreneurial activity tends to increase by $11.22 \%$. This contribution is not too high compared to emotional support. However, education needs to be improved so that the knowledge of new entrepreneurs will be better so that it supports their competence and passion. Thus, three variables contribute to entrepreneurial passion of $44.17 \%$ or equivalent to the $\mathrm{R}^{2}$ value. This means that $65.83 \%$ of passion is influenced by other variables such as in the study of [1]. These factors are in the form of personal and contextual antecedents.

\subsection{Discussions}

Emotional support leads to accepting seed early financing when starting a business. The funds come from investors, parents, government, or banks. Relevant to the [5] for the entrepreneurs who perceive the emotional support can increase their persistence along with increasing entrepreneurial passion. In line with Social Learning Theory, reinforcement is a response from others that can strengthen or weaken a person's behavior. Thereby, emotional support, e.g. seed early financing, facilities, or others, will strengthen a person's behavior so that he/she is more eager to develop a business or is sure to start a new venture. This sense of confidence stimulates the formation of entrepreneurial passion. This study identifies the lowest value of the emotional support indicator on ES3 so that the provision of initial financing is needed by new entrepreneurs. Thus, this mechanism can be more foster an attachment to entrepreneurship.

Moreover, the result of perceived competence is suitable with [5] where the perceived task-competence affects the belief in getting opportunities. This effect can foster entrepreneurial passion among entrepreneurs. Previous beliefs and experiences generate positive feelings that foster a passion in creating the product/service, founding and developing the venture. When an entrepreneur has positive experiences in the past, it will generate positive emotions and confidence in running a business so can increase the passion or vice versa. However, this study found the lowest validity score on PC3 so that in fact the majority of entrepreneurs needed to have their licensing facilitation. Through the assistance of the government will solve licensing problems so that they will be more passionate about building a business.

Regarding the educational aspect, the result is suitable of [6], entrepreneurial education can foster a person's selfefficacy so that this feeling can stimulate entrepreneurial passion. This mechanism is in line with the social learning theory. Basically, education can be done through formal education or the results of practice in carrying out activities so that entrepreneurs must have an orientation to gain or increase knowledge related to their fields. Entrepreneurs must be able to educate themselves to always learn from the environment so that they will strengthen their confidence in developing ideas, gathering resources, and managing and operating entrepreneurial activities. This method can overcome the limitations of the EE1 indicator whereas it has the lowest score of entrepreneurial education validity. Thereby, this shows the role of education is very important in forming a strong and passionate person in building entrepreneurship. For this consideration, needed educators and government policies to support the passion among entrepreneurs in Indonesia.

In aligning with the statement of Leach and Melicher defined entrepreneurship as "the process of changing ideas into commercial opportunity and creating value" [17]. In reality, it is not easy to realize opportunities commercially or even provide financial output. It takes perseverance to undergo the entrepreneurial process where persistence itself is an energy generated by a strong passion for entrepreneurship. This is in line with Murnieks et al. who highlighted that passion provides energy in carrying out entrepreneurial activities [18]. This spirit will ultimately generate outcomes or value for entrepreneurs. Therefore, passion will lead to persistence, positive feeling, creativity, and venture sustainability [9],[3],[11]. Therefore, the passion must be cultivated for new entrepreneurs so that in the future they can manage their business to achieve success. It is to overcome the lowest score of validity on EP7 among entrepreneurial passion instruments. 
Synergy and continuity improvement on these variables (e.g., emotional support, perceived competence, and entrepreneurship education) will further strengthen the existing passion for new entrepreneurs. Educational institutions and the government have the responsibility in building an entrepreneurial atmosphere so that it will automatically build an entrepreneurial passion for the younger generation. Moreover, it can ensure the shaping of entrepreneurial intention for nascent entrepreneurs [1920]. Based on this mechanism, it is a step in achieving the target of the ideal number of educated entrepreneurs.

\section{CONCLUSION}

The results of this study can identify the significant impact between emotional support, perceived competence, and entrepreneurial education on entrepreneurial passion among entrepreneurship in Jakarta. In Social Learning Theory, there is a reciprocal relationship between personality, behavior, and environment. This means that a person's behavior can be influenced by personality and environment as well as these two aspects. To foster passion awareness, the role of the social environment is important. The collaboration among stakeholders e.g., government, institutional education, investors, financial institutions, corporations, or others can encourage entrepreneurship development to increase self-confidence and enthusiasm for the stages in the entrepreneurial process. This is a suggestion for the stakeholders.

For future studies can improve with other variables in the form of personal and contextual antecedents. It is depicted in "nomological network of variables to entrepreneurial passion" by the study of [1]. The involvement of these aspects will capture a lot of information in understanding the relationship between antecedents and outcomes of the entrepreneurial passion, especially for new entrepreneurs. Lastly, the limitations of the study involve as many as 100 entrepreneurs, so this study has not been able to capture the overall behavior of entrepreneurs in DKI Jakarta. Therefore, in addition to adding variables, further research can involve more respondents by distinguishing from female and male new entrepreneurs.

\section{ACKNOWLEDGMENT}

This work was supported by Tarumanagara University Research and Community Service Institute in 2020 by the contract of SPK No: 1642Int-KLPPM/Untar/XII/2020 for final assignment scheme. Thanks to entrepreneurs in DKI Jakarta for their willingness as respondents in this study.

\section{REFERENCES}

[1] A. Newman, M. Obschonka, J, Moeller, G.G. Chandan. "Entrepreneurial passion: A review, synthesis, and agenda for future research", Applied Psychology: An International Review, 2019, 0(0), pp. 1-45 DOI: 10.1111/apps.12236.

[2] I. Syed, J.C. Butler, R.M. Smith, X. Cao. "From entrepreneurial passion to entrepreneurial intention: The role of entrepreneurial passion, innovativeness, and curiosity in driving entrepreneurial intentions", Personality and Individual Differences, vol. 157, 2020, https://doi.org/10.1016/j.paid.2019.109758.

[3] M.S. Cardon, C.P. Kirk. "Entrepreneurial passion as mediator of the self-efficacy to persistence relationship", Entrepreneurship: Theory and Practice, 39(5), 2013, pp. 1027-1050. DOI: 10.1111/etap.12089.

[4] M.S. Cardon, M.D. Foo, D.A. Shepherd, J. Wiklund. Exploring the Heart: Entrepreneurial Emotion is a Hot Topic, Entrepreneurship Theory and Practice, 36, January, 2012, pp. 1-10. DOI: 10.1111/j.15406520.2011.00501.x.

[5] P. Stenholm, M.S. Nielsen. Understanding the emergence of entrepreneurial passion: the influence of perceived emotional support and competences, International Journal of Entrepreneurial Behavior and Research, 25 (6), 2019, pp. 1368-1388. DOI 10.1108/IJEBR-02-2018-0065

[6] M. Arshad, O. Farooq, S. Afzal. "The role of entrepreneurship education in developing a passion for business", Global Business and Organizational Excellence, 38, Issue 1, 2018, pp. 15-21. https://doi.org/10.1002/joe.21896

[7] Y. Kaijun, P. I. Sholihah. "A comparative study of the Indonesia and Chinese educative system concerning the dominant incentive to entrepreneurial spirit (desire for a new venturing) of business school students", Journal of Innovation and Entrepreneurship, 2015, pp. 1-16. DOI: 10.1186/s13731-014-0014-0.

[8] M. Obschonka, J. Moeller, M. Goethner. Entrepreneurial passion and personality: the case of academic entrepreneurship, Frontiers in Psychology, vol. 9. January, 2019. pp. 1-15. DOI: 10.3389/fpsyg.2018. 02697.

[9] M. S. Cardon, J. Wincent, J. Singh, M. Drnovsek. The Nature and experience of entrepreneurial passion, Academy of Management Review, Vol. 34, No. 3, 2009. pp. 511-532. DOI: 10.5465/AMR.2009.40633190. 
[10] M.S. Cardon, J. Wincent, J. Singh, M. Drnovsek. Entrepreneurial passion: the nature of emotions in entrepreneurship, Academy of Management Best Conference Paper. 2005. pp. 1-7.

[11] M.S. Cardon, D.A. Gregoire, C.E. Stevens, P.C. Patel. Measuring entrepreneurial passion: conceptual foundations and scale validation. Journal of Business Venturing, 28(3), 2013, pp. 373-396.

[12] M.S. Cardon. "Is passion contagious? The transference of entrepreneurial emotion to employees", Human Resource Management Review, 18(2), 2008, pp. 77-86. DOI: 10.1016/j.hrmr.2008.04.001.

[13] P. Merieska, J.J.K.S, Meiyanto. "Passion berwirausaha pada pengusaha muda", Gadjah Mada Journal of Psychology, vol. 3(1), 2017, pp. 13-24

[14] M.A. Siddiqui. "Entrepreneurial passion as mediator of the entrepreneurial self-efficacy and entrepreneurial performance, relationship: an empirical study in small medium businesses", Journal of Entrepreneurship \& Organization Management, vol. 5 (3), 2016, pp. 1-7. DOI: 10.4172/2169-026X.1000200.

[15] P. Davidsson, B. Honig. "The role of social and human capital among nascent entrepreneurs", Journal of Business Venturing, 18, 2003, pp. 301-331. DOI: 10.1016/S0883-9026(02)00097-6.

[16] D. Vandewalle. "Development and validation of a work domain goal orientation instrument", Educational and Psychological Measurement, vol. 57, No. 6, December, 1997, pp. 995-1015. DOI: $10.1177 / 0013164497057006009$.

[17] J.C. Leach, R.W. Melicher. "Entrepreneurial Finance", Fourth Edition, South-Western Cengage Learning, 2011.

[18] C.Y. Murnieks, E. Mosakowski, M.S. Cordon. "Pathways of passion: Identity centrality, passion, and behavior among entrepreneurs", Journal of Management, vol. 40(6), September, 2014, pp. 15831606. DOI: $10.1177 / 0149206311433855$.

[19] K. Nuringsih, I. Puspitowati. "Determinants of eco entrepreneurial intention among students: Study in the entrepreneurial education practices", Advanced Science Letters, 23(8), 2017, pp. 7281-7284. DOI: 10.1166/asl.2017.9351.

[20] K. Nuringsih, M. N, Nuryasman, I. Prasodjo, R. Amelinda. "Sustainable entrepreneurial intention: the perceived of triple bottom line among female students", Jurnal Manajemen, Vol. XXIII(02), June, 2019, pp.
168-190. DOI: http://dx.doi.org/10.24912/jm.v23i2. 472. 